\title{
Social Status Shift and Collapse of Uleebalang in Aceh of 1900-1946
}

\author{
Muhammad $^{1}$, Sukiman $^{2}$, Irwansyah $^{2}$ \\ ${ }^{I}$ Ph.D Student in State Islamic University of North Sumatera (UINSU), Medan, Indonesia \\ ${ }^{2}$ Lecturer in State Islamic University of North Sumatera (UINSU), Medan, Indonesia \\ Sagmuhammad@yahoo.com
}

\begin{abstract}
This paper explores the Social Status Shift and Collapse of Uleebalang in Aceh of 1900-1946. The conflict between ulama and ulebalang increasingly entered a critical phase, especially after news of Japan's defeat. This research is conducted by using qualitative research design. The results shows that the surrender of the uleebalang did not dampen the ulama's determination to continue to expel the Dutch from the land of Aceh in various regions, both in Aceh City, Pidie, North Aceh, West Aceh, Central Aceh and Southeast Aceh fall on the battlefield. The Aceh War had a great impact on the people of Aceh, especially the scholars. The direct impact of the Aceh war can be seen from the division of ulama into three groups, there are 1) The ulama who was the Kadli in the government of the uleebalang who recognized Dutch sovereignty; 2) The ulama who only give religious lessons in dayah-dayah; and 3) The ulama who still continued the struggle against the Dutch. In addition, the fundamental impact is the strengthening of the position of ulama in Acehnese society. Another impact is the widening of the distance between the ulama and the uleebalang. The Dutch tried to break the Acehnese community through politics.
\end{abstract}

Keyword : Social Status Shift; Uleebalang; Aceh

\section{Introduction}

Since the Dutch could take control of Aceh, the position of the ulama began to shift, because the Dutch surrendered government affairs to ullebalang (hulubalang), while the ulama were only given the qadhi position (the judge who ruled the case). Meanwhile the ulama continued to struggle with the people to expel the invaders and to stand up as the leaders of the people informally. Thus, the leaders of the state and politics in Aceh changed until the Japanese occupation. At the beginning of the independence of the Republic of Indonesia, a number of scholars had been able to fill important posts in government in Aceh, even most of them were charismatic formal leaders in the midst of society.

The role of ulama directly in politics also has an impact on the spread of Islamic political morals in the world of politics in our nation. Especially when the ulama became leaders and leaders in the world of politics in a society, Islamic political morals that he carried out would easily become a political moral in the politics of the community in general.

The mention of uleebalang (or hulubalang in Malay) actually has a number of interpretations in the system of customary governance in Aceh, especially in the system of governance of the Sultanate of Aceh Darussalam during the reign of Sultan Iskandar Muda (1607-1636), and also in the governance of other Malay kingdoms generally.

In a special context, the uleebalang is an administrative position given to people from aristocratic groups in Acehnese society to lead a state or nanggroe, namely district-level territory in the present structure of Indonesian government. Uleebalang is known as Teuku for men or Cut for women. However, in its later development, the uleebalang was interpreted more broadly, namely the position of high official in the government of the kingdoms in Aceh, both before and after the arrival of Islam. 
The average Uleebalang consists of people who are open and cosmopolitan. Their high level of education and their extensive association make the uleebalang easy to socialize and include being open to receiving outside influences. During the Dutch colonial period, the uleebalang became a party on the front line in establishing relations with foreigners.

The role played by the uleebalang actually made their image in some circles, especially among the ulamas, to be bad and even often accused of being traitors or henchmen of invaders. Another factor that was not less decisive was the policy of devide et impera or the strategy of splitting which was applied by the Dutch during colonialism in Aceh. The agreement on a political contract between the Dutch and the kingdom indeed often involved the uleebalang.

The Uleebalang which is believed to be zelfbestuurder in the sultanate period is an absolute small 'kings'. They held power from generation to generation in the name of the sultan. But the longer the power held by the Uleebalang, the bond becomes weak and then decides and separates from the sultan's government secretly. This separation is of course facilitating the invaders who entered Aceh to influence the small kings. The Uleebalang which previously worked hand in hand with the ulamas fighting the Dutch colonizers, gradually changed and took sides and were loyal to the Netherlands. While the ulama never accepted Dutch rule. Therefore, it is not surprising that in March 1942 when a rebellion against the Netherlands and the ulama who joined the All Aceh Ulama Association (PUSA) allowed and cooperated with Japan to enter Aceh. These factors continue to exacerbate the relations between the two parties. Ulama finally made a decision to fight the Uleebalang with the intention of removing the system of feudal government together with Dutch rule when the Pacific war broke out.

Even though the uleebalang was the ruler but the position of the ulama was no less important, this was understandable because the life of the Acehnese people was dominated by religious values so that the existence of ulama was very close to people's lives. Politically the three pillars, sultan, ulama, uleebalang are interrelated and influence each other. The Sultan needs the uleebalang as a liaison with ordinary people.

The award enjoyed by the Ulama in this case does not only come from the upper classes of society, but also from ordinary people. Even though those who became rulers were the Uleebalang, the position of the Ulama was no less important. According to Misri A. Muchsin, the position of Ulama in Acehnese society was so strategic, namely not only as religious leaders, but also as political leaders and war leaders. The Dutch War in Aceh had shown that the Ulama were at the forefront of mobilizing forces to fight Dutch colonialism in Aceh. Even the Ulama who have instilled the ideology of sabil war to the community, especially to the Aceh army. This fact is understandable, because in a society dominated by spiritual values, then by itself the position of the Ulama is very close to the community, it can even be said to be in the heart.

\section{Literature Review}

\subsection{Ulama}

Etymologically "Ulama" in Arabic is the plural form of "alim", which means people who are knowledgeable, scientists, scholars, experts, or experts in the field of Islamic religion. This predicate is of course given to someone who truly masters a particular field in Islamic studies. This great achievement is not easily obtained, but given to someone who has been proven to master certain aspects in the field of Islamic studies. Because of the weight of his expertise, a person can be trusted to have expertise and authority in the field of expertise. 
In the Indonesian context, scholars also have different names in each region such as; Kyai (Javanese), Ajengan (Sunda), Tengku (Aceh), Sheikh (North Sumatra / Tapanuli) and Tuan Guru (Nusa Tenggara and Kalimantan). Science is masdar taukid from the verb 'alima which means knowledge. Science is different from ma'rifah which also means "knowledge". In the original sense, the first term. Refers to knowledge of the highest quality which can sometimes be obtained only intuitively, while the second term refers to knowledge in general. In classical usage, ilm does not have the plural in accordance with the unity of the concept of $i l m$ itself in the earliest times of Islam. However, in post-classical Arabic, the plural form is introduced, that is 'ulum, which refers to various' ilms of several types of knowledge.

\subsection{Position of Ulama as Members of the Community}

Here it can be emphasized that the position and role of the Ulama is very important and focused on two things. First, they weigh the expertise and ulama of each of them, and at the same time act as "enlighteners" in the minds of the people. The scholars, in accordance with their respective disciplines play an active role in "educating" the lives of the people. The thought of the scholars became scientific reference material that was always held and continuously explored to always be developed creatively. Legal fatwas produced by the Ulama have always been a reference to knowledge, have become the basis of moral guidance and become a legal reference so that the people are not swayed in uncertainty, especially in the face of the complexity of social problems that always arise in this life in accordance with the pace of modernity.

Second, the central position and strategic role of Ulama is as a role model for the people. Moral quality that is well demonstrated and exemplified by the Ulama reflects the value and civilization of a Nation. Indonesian Muslims and Nations are currently experiencing a wave of transformation from traditional societies to modern societies or from agrarian societies to industrial societies. In such circumstances, there is a flow of struggles and struggles in values in various aspects of social life.

With a good, noble and noble moral example of these Ulama, it will get examples and moral guidance so that the people will not lose direction and control in navigating the ark of this life. Yusny Saby in his book A profile of the Ulama in the Acehnese Society, states that there are three functions of Ulama in community life, namely as an ordinary person (community member), as heir to the prophets (warasatul anbiyaa), and as a mother (pengayom) of the community.

\subsection{Ulama as Qadhi (Chair of the Religious Courts)}

The separation between religion and state in the period after the leadership of khulafa arRashidin became clearer with the position of the ulama as the king's advisor (Qadhi), he served as a judge in every dispute resolution, especially those related to religion. The judges' decisions became a fatwa that was used as a reference in a government process led by a caliph. This continued until the end of the Islamic Caliphate.

Furthermore, after the collapse of the Islamic Caliphate, the Islamic world was in the grip of European colonialism so that it was inevitable that Muslims would be kept away from the ulamas. Although efforts to position ulama as partners of the country's leaders continued to be carried out, the condition of the colonized Muslims forced Muslims to further narrow the role and position of the ulama. Then what happens is that the ulama is only limited to giving fatwas 
in household matters, inheritance and civil matters. While broader issues relating to statehood can hardly access it anymore.

This situation is the background for some scholars in India to try to fight for the existence of ulama, besides trying to protect Muslims from various pressures from internal and external enemies. So in 1947 Ali Jinnah a scholar from India founded the State of the Islamic Republic of Pakistan. This effort is based on the initial principle that the role and position of the ulama should not be separated from government, in this case the Islamic government should properly make the ulama as a guideline in the implementation of its policies.

After that, following the Shi'a group which was pioneered by Ayatullah Khumaini with its main struggle to build an Islamic government which was the religion of making the role of the ulama as the central figure in every state policy. The Islamic Revolution which he moved in 1979 resulted in the formation of the State of the Islamic Republic of Iran. Wilayatul faqih as the ulama assembly became a central position in the Iranian government.

From the phenomenon of the two models of Islamic governance, several opinions emerged among Muslim modernist scholars regarding the position and role of the ulama, there were two opinions on matters; this, is he just an advisor to the head of state? Or also become an executor in state policy? The first opinion stated that the ulama were enough to become $u s t a d z$, buya or preachers who came to worshipers or worshipers who came to study or asked for a fatwa. The matter of his life, leave it to his other initiatives, or his side profession or his other main profession. For this one understanding, scholars are not a profession but a noneconomic service function. In fact there is an assumption that the ulama are not worth paying if they come to give a recitation. Recitation is only a sacred task.

\section{Discussion}

The conflict between ulama and ulebalang increasingly entered a critical phase, especially after news of Japan's defeat. The news that Japan's defeat in the new Aceh was officially announced on August 23, 1945 and only on August 25, the Japanese government issued a declaration to all Acehnese who stated that the war was over and Japan had surrendered to the allies. On August 27, allied warplanes dropped leaflets stating that the war had finished Japan had claimed defeat.

Since then the Acehnese have argued that the Dutch will come on behalf of the allies. Therefore the group that blatantly fought the Dutch at the time of the Japanese arrived, in this case the PUSA became anxious. Whereas the group that was excluded from the Japanese occupation at that time, namely the uleebalang felt happy and prepared to welcome the arrival of the Dutch.

For the general population in this area at that time it was an inevitable fact that the recapitulation of Japan meant the return of the Dutch to the Aceh region. It does not occur to them that with Japanese recapitulation the possibilities in relation to changes in the state constitution will arise. The people in this waiting period are divided into three groups, first, the biggest group that awaits everything calmly does not take the attention that might occur. This group is a group that is not politically oriented and accepts everything with open arms. Second, groups consisting of those who were very happy over the recapitulation of Japan, this group aspires to return Dutch rule to the homeland. In this group are those who during the Dutch had a high position that gave them the opportunity to live in luxury. Japan's recapitulation of this group meant the return of Dutch power and the return of Dutch power to the return of their 
lives filled with pleasure, splendor, and luxury, they were the uleebalang. Third, groups consisting of those who even at birth appear calm, but their hearts are in an agitated state.

They were worried about the consequences that would later arise if Japan disappeared and the Dutch again occupied this area. In the beginning there did not appear to be anything that would become the subject of a dispute between the two groups, but gradually things appeared to cause conflict between one another. The group that wanted the return of Dutch rule began to try to collect materials regarding the behavior and actions of the latter groups during the Japanese occupation. They began to carry out tactics to find out and record the names of everyone who had collaborated with Japan and everything that could put pressure on this collector. The reaction from the tricked party arises immediately so the situation becomes precarious.

The activity of the uleebalang group as mentioned above by the ulama group is seen as an indication that the uleebalang's efforts which for some time after the Aceh war had betrayed the homeland by siding with the Dutch, wanted to betray for the second time. The situation became tense when each party arranged a line, preparing to face the possibility that would occur. However, this situation did not last long because the youths who worked at the Domei Japanese news agency in secret managed to hear the news of the Indonesian proclamation of independence.

Furthermore this news quickly developed among government agencies. News of the proclamation of Indonesian independence was immediately welcomed by all Acehnese people. This news was also welcomed by the clerics. In a short time they became Republicans. Teungku Daud Beureueh as chairman of the PUSA called on all people to prepare to defend the republic and eradicate the Dutch lackeys from Aceh. Red and white flags were immediately raised at PUSA offices.

The use of the name PUSA slowly began to recede and changed the term republicans or revolutionaries. On the contrary the feudalists (uleebalang) were named NICA or counterrevolutionaries. The scholars as one of the influential groups in Acehnese society saw that the proclamation of Indonesian independence was something that neither Japan nor the Netherlands liked, they openly wanted to restore their colonial rule with the power of firearms.

The uleebalang who had been accustomed to standing since the era of the kingdom of Aceh faced with these changes gave rise to greater suspicion towards the ulama group. The Uleebalang feels as if his position will be displaced and their power will collapse at any time. The ulama group was seen as the main source of their collapse. The Republican government formed in Kutaraja in early October 1945 showed collaboration between the ulama and uleebalang who were anti-Dutch. It seems that the ulamas allowed the uleebalang to occupy important positions in the local government due to the clerics' concern about the return of the Dutch.

Teuku Nya Arif uleebalang from a nangroe in large Aceh became a resident of Aceh, in his staff including PUSA chairman Daud Beureuh who became head of the Office of Religious Affairs and a member of the regional national committee. However, competition between ulama and uleebalang continued in the Republican ranks, especially among the youth. When his resident Arif founded the API (Indonesian Youth Force) which was a national army embryo in the Aceh region, his officer corps was dominated by Gyugun officers who were oriented to the uleebalang and not to PUSA.

The establishment of the API was immediately followed by the Indonesian Youth Association which later became the Indonesian Socialist Youth which was controlled by young 
people oriented to PUSA. This republican government, which was greatly influenced by the nobility in Aceh, failed to get support from many other uleebalang. Therefore a series of physical conflicts broke out called the cumbok war.

President Soekarno named the event a social revolution because it involved two national forces in conflict with one another. In the event involved ulama and uleebalang elements, the ulama sided with the general youth and they opposed the behavior of the uleebalang which was unfair. The uleebalang and their families are in one camp with people who have been benefited from the hereditary system for generations. Cumbok is the name of the sub-district included in the Lam Meulo marriage district of North Aceh.

Before the independence of the Republic of Indonesia, Aceh Pidie included three municipalities, namely Sigli, Lam Meulo, and Meuredu, in the period of the North Aceh republic divided into three districts

a. Aceh Pidie, consisting of Sigli, Lam Meulo and Meuredu marriages

b. North Aceh, consisting of the marriage of Lhok Seumawe, Lhok Sukun and Bireuen

c. Central Aceh, consisting of kawedanan Takengon, Kuta Cane and Blang Kejeren.

The last sub-district head of Cumbok in the Netherlands called Zelfberstuurder Van Cumbok was uleebalang Teuku Muhammad Daud who was known as Teuku Cumbok during the Japanese occupation who became Gunco Lam Meulo later when Indonesia became independent, because it desperately needed people who had expertise in government so he was appointed became Lam Meulo wedana and received the title Sri Muda Pahlawan Bintara Cumbok.

David Cumbok was one of several uleebalang who blatantly showed a lack of support for Indonesian independence. He hesitated and saw that the Indonesian nation was not yet able to be independent, because we were not yet mature and as soon as possible the Dutch would return to Indonesia to rule.

When receiving a wire letter from the Aceh Resident who explained that Indonesia had been independent and asked to raise a red and white flag at Lam Meulo, the letter was laughed at and torn apart. Likewise, the declaration and news of the independence of the Republic of Indonesia which were posted on the streets of Lam Meulo by young people of BRI (Barisaan Republik Indonesia) were torn apart. On October 12, 1945 in the office of Bunco Lam Meulo, a red and white flag was raised by the ranks of the people, but Teuku Cumbok ordered him to immediately lower it.

Teuku Daud Cumbok is also known as a person who likes to act rather than diplomacy, so it seems arrogant and like to take light of others. As seen when holding a night market in Lam Meulo in November complete with gambling arena. At the party he drunk intoxicated regardless of the advice of the invited scholars. Even tend to harass by saying "I want to repent so that I become God's beloved person like Teungku but let the night market run out, and let the world first enjoy pleasure".

The perfection of this BPK weaponry was as a result of the flow of financial assistance from other parties mostly from the uleebalang throughout Aceh, in addition to some weapons obtained from the Japanese. The power of the BPK has a hundred weapons including cannons and mortars. This line was formed from former KNIL members who were trained to use weapons by Japan. The BPK is led by Teuku Mahmud which is then grouped into three units.

a. The line of Cap Bintang, with the main task of facing the people's resistance against the authority of the uleebalang 
b. The Cap Sauh line, with assignments in finance to finance their movements, for that they burned houses and robbed people of their assets against the uleebalang

c. The Tombak Cap Barisan, which was tasked with arresting the ulema and the PRI leaders who opposed it, would obstruct them.

Seeing the preparations that were very far from the uleebalang and worried that the uleebalang's actions would cause a similar reaction from the uleebalang, the Kutaraja government tried to resolve the dispute peacefully. But the effort was unsuccessful. Even the Barriers to Security Guard were trained until near November 1945, so they were ready to attack and confront their opponents. On October 25, 1945 the uleebalang began acting by ordering the arrest and detention of several young men assigned to guard the post office and telephone office in Lam Meulo.

Then on the night of November 8, 1945, the order of the Uleebalang Headquarters was carried out seizure and mastery of the places for meeting young people in Lam Meulo. Then cleaning the city of Lam Meulo was carried out by members and leaders of the independence fighters. The youths were no longer permitted to live in their own courtyard, so that it could be said that the Uleebalang Headquarters had succeeded in destroying the movements of their opponents in Lam Meulo and that they could be completely controlled.

This has aroused the anger of the people who disagree with the actions of the uleebalang headquarters. As a ruler, Daud Cumbok has the right to be responsible for maintaining security and order as a whole, therefore he has spread guard and banned outsiders from entering Lam Meulo and detained people who opposed him, including the PUSA youth.

Besides that he forced Japanese commanders to hand over weapons to the BPK. In the Lam Meulo area there are indeed many Japanese armory warehouses, food warehouses and clothing warehouses, so Daud Cumbok as the Gunco area can easily get these Japanese deposits.

The actions taken by Teuku Daud Cumbok and the BPK certainly caused disappointment and concern as well as the anger of the PUSA youth and scholars. Therefore the PUSA cleric and API leader urged the Japanese commander not to hand over weapons to the uleebalang party which was deemed to endanger public security. After the uleebalang succeeded in taking control of Lam Meulo as the base of defense, they mobilized troops to take control of Garot which was the center of the struggle of the PUSA and PRI. From Garot they planned an attack on a strategic Sigli, by mastering Sigli transportation in all majors can be mastered.

The atmosphere became increasingly tense when the BPK and a large number of residents around Sigli followed the uleebalang complete with weapons entering the city of Sigli on 12 November around 12pm and took preparations to take control of the city of Sigli by placing guards at strategic locations and holding traffic control and holding supervision of everyone who goes in and out of the city of Sigli. Seeing this situation, the PRI leader mobilized his followers from Garot and Gigieng to surround the city of Sigli.

Thousands of people were around the city of Sigli on alert, while the troops inside the city were completely besieged. In a critical situation like this Teuku Nyak Arif resident of Aceh sent Syamaun Gaharu with a small force of API / TKR to try to find a peaceful solution. Also came the Commander of the Polim representing the Aceh government and Teuku Jhohan Meuraxa as deputy governor of Sumatra. In the negotiations held by the disputing parties, an agreement was finally reached that the weapons were handed over on December 4 to the TKR.

When paying attention to the ulama leadership in mobilizing anti-Cumbok forces it has become a great force that has succeeded in destroying the uleebalang's power throughout Aceh. 
After the Cumbok war ended, the position of the uleebalang in Aceh declined. His position as head of ethnic, the head of government that he held for decades, even for centuries has now turned to the clergy who won the war. The cleansing movement against the uleebalang elements did not stop until just in the Piddie region, but extended throughout the Aceh region. Opposing groups of the uleebalang conducted a coup against the civilian and military government of the Acehnese residence. Teungku Amir Husin Al Mujahid has mobilized his followers to arrest all uleebalang, including those who sit in government and the army.

Teuku Pidie who was assistant to the resident of East Aceh and Teuku Alibasyah Wedana Langsa was arrested who was later killed by the PUSA group on charges of supporting Cumbok.

On February 14, 1946, Teuku Panglima Polim held a meeting with uleebalang XXII Mukim in Lam Sie. In the meeting a resolution was issued

a. That the hereditary thing has become a habit for centuries for the uleebalang to rule the country today is no longer compatible with the times.

b. That we are ulebalang citizens of the Republic of Indonesia and respect the sovereignty of the people.

c. That to create a perfect government atmosphere we decided:

1) Appealing to the government so that the people in XXII Mukim are given the right to determine their heads and heads down.

2) All uleebalang (including the sagi commander) should now be allowed by the government to put their respective positions in place to give the opportunity for the people to choose their heads

3) Delivering this resolution to His Excellency His Excellency Mr. President of the Republic of Indonesia, Your Excellency the Great Lord of the Governor of Sumatra, His Excellency the Great Lord of the Resident of Aceh, and broadcasting to all Indonesian people with newspaper bro.

Many of the uleebalang-uleebalang descended themselves from their positions, some of which were revealed in the cleansing movement carried out by the People's Struggle Army (TPR) in March 1946 under the leadership of Husin Al Mujahid. With the end of the social revolution in Aceh, the system of feudal government which was entrenched in Acehnese society became the backbone of the Dutch East Indies government in Aceh. On the ruins of the feudal system, a democratic system has been established by the people, from the people to the people, which is now enjoyed by all the people of society from various groups and layers.

In every afdeeling (regency), now the scholars are leaning towards the PUSA who occupies the most important positions, with non-Acehnese employees and nationalist youth who can work with them. The new regional government set up a commission to investigate the wealth of the uleebalang who died killed as traitors, especially in Pidie. About 100 million rupiahs are estimated to have fallen into the hands of the conquerors, and some are still in their hands in return for their services or in compensation for the losses they experienced in the uleebalang's former power. But most of it has been submitted to the government which is one source of wealth to pay salaries for employees and the army. The vast lands that were once owned by uleebalang returned to the farmers who used to hold them seized by their rulers. Some remain administered by the government, and some are returned to the surviving uleebalang families.

The arrests also opened up opportunities to make changes at the village level. Landscape which was formerly ruled by the uleebalang on the basis of an absolute system of small type 
monarchies under the Dutch environment, was overhauled into sub-districts governed by the camat on the basis of a democratic system that originated from the 1945 Constitution.

Each uleebalang has been replaced by one committee consisting of five people, who work during the transitional period for several months, before village heads can be elected in each village. Many disliked keuchik were replaced, especially in Pidie and the north coast. Ulama and religious teachers were the place to ask villagers to get guidance and guidance during this extraordinary new period. The direct result of this event was a refresher and democratization of the Acehnese people, everything that had become a thorn in the eyes of the Acehnese during the rule of the uleebalang in the villages was abolished. Agriculture, plantations, farms are cultivated by the people themselves.

The birth of this new form of bureaucracy has changed the size of the power and status of a leader. The leadership of the Acehnese community was previously centered on the uleebalang. The leaders under him such as Teuku imeum, the head of the mukim and the keuchik used the power of the uleebalang in order to carry out their influence in society. The leadership process took place based on kinship and descent systems specifically for the uleebalang and the appointed teuku imeum of the descendants of the nobility.

While the keuchik itself was chosen by the uleebalang. However, it was unavoidable that the influence of the conflict between the ulama, especially the PUSA clerics and the uleebalang, had led to a change of formal leadership from the aristocratic class to the ulama group. The occurrence of massacres in the conflict has changed the status of the Uleebalang family no more and no less as one of the various social groups in the community, different from their previous status as the main people and nobles.

\section{Conclusion}

In addition to mobilizing power, ulama were also directly involved in wars in various regions, although many uleebalang had recognized Dutch sovereignty in Aceh. The surrender of the uleebalang did not dampen the ulama's determination to continue to expel the Dutch from Aceh land in various regions, both in Aceh Besar, Pidie, North Aceh, West Aceh, Central Aceh and Southeast Aceh ulama together with the people who did not recognize Dutch sovereignty tried to continue to fight even willingly fall on the battlefield.

The Aceh War had a great impact on the people of Aceh, especially the scholars. The direct impact of the Aceh war can be seen from the division of ulama into three groups, there are 1) Ulama who was the Kadli in the government of the uleebalang who recognized Dutch sovereignty; 2) Ulama who only give religious lessons in dayah-dayah; and 3) Ulama who continued their struggle against the Dutch. In addition, the fundamental impact is the strengthening of the position of ulama in Acehnese society. Another impact is the widening of the distance between the ulama and the uleebalang. The Dutch tried to break the Acehnese community through politics.

\section{References}

Abdullah, Taufik, (ed), Sejarah Lokal di Indonesia: Kurapulan Tulisan, Yogyakarta: Gadjah Mada University Press, 1996.

-------------, Agama dan Perubahan Sosial, Jakarta: Rajawali, 1988. 
Abubakar, Said Berjuang Untuk Daerah Otonomi Hak Azazi Insani. Aceh: Yayasan Nagasaki Banda Aceh, 1995.

Ahmad, Zakaria, Sejarah Perlawanan Aceh terhadap Imperialisme Kolonialisme di Daerah Istimewa Aceh, Banda Aceh: Yayasan Pena, 2008.

------------, Sejarah Perlawanan terhadap Imperialisme dan Kolonialisme di Daerah Istimewa Aceh, Banda Aceh, Balai Kajian Sejarah, 1991.

-----------, Sekitar Keradjaan Atjeh dalam tahun 1520-1675, Medan:: Monora, 1972.

Al-Faruqi, Ismail Raji, Tauhid, Bandung: Pustaka, 1995.

Alfian, Ibrahim, (eds.) Segi-Segi Sosial Budaya Masyarakat Aceh: Hasil-Hasil Penelitian Dengan Metode “Grounded Research." Jakarta: Lembaga Penelitian Pendidikan dan Penerangan Ekonomi dan Sosial. 1977.

------------, Dari Babad dan Hikayat sampai Sejarah Kritis, Yogyakarta: Gadjah Mada University Press, 1987.

-------------, Kelompok Elit dan Hubungan Sosialdi Pedesaan. Jakarta: Pustaka Grafika Kita, 1988.

------------, Perang di Jalan Allah: Perang Aceh (Jakarta: Pustaka Sinar Harapan, 1987.

--------, Perang di Jalan Allah: Perang Aceh 1973-1912, Jakarta: Pustaka Sinar Harapan, 1987. , Wajah Aceh dalam Lintasan Sejarah, Banda Aceh: PDIA, 1999.

1982.

Amin, Ahmad, Dhuha al-Islam, Cairo: Maktabah an-Nahdhah al-Mishriyah, 1975.

Ankersmit, F.R., Refleksi Tentang Sejarah: Pendapat-pendapat Modern tentang Filsafat Sejarah. Terj. Dik Hartoko, Jakarta: Gramedia, 1987.

Anwar, Rayyati M Zain, Teungku Haji Ahmad Hasballah Indrapuri Sebagai Tokoh Pendidikan Di Aceh.” Tesis, IAIN Ar-Raniry, 1986.

Ara, LK., Ensiklopedi Aceh: Adat, Hikayat dan Sastra, Banda Aceh: Yayasan Mata Air Jernih, 2008.

Arief, Sanusi M. Gampong dan Mukim di Aceh Menuju Rekonstruksi Pasca Tsunami. Bogor: Pustaka Latin. 2005.

Arifin, A. Hadi, Malikussaleh, Lhokseumawe: Unimal Press, 2005.

Armstrong, Karen, Sepintas Sejarah Islam, Yogyakarta: Teralitera, 2003.

Azra, Azyumardi, Jaringan Ulama Timur Tengah dan Kepulauan Nusantara abad 17-18. Bandung: Mizan, 1995.

Bakker, J.L. (Hans). The Aceh War and the Creation of the Netherland East Indies State; In Great Powers and Little Wars The Limit of Power, London: Praeger, 1993.

Beamer, Chareles. R., The Acehnese-Dutch War and its Effec For Acehnese People: Their Land, Costumes and Institutions. Dalam Conference On Modern Indonesian History, July $18-19,1975$.

Berkhute, Jr. Robert, A Behavioral Approach to Historical Analysis, New York: The Free Press, 1971.

Brakel, L.F., "Negara dan Kenegarawanan Aceh di Abad XVII" Dalam Dari Sini Ia Bersemi, Sri Suryanta, Dinamika Peran Ulama Aceh, Jogjakarta: Ak Group kerjasama dengan ArRaniry Press, 2008.

Budiardjo, Miriam, Dasar-dasar Ilmu Politik, Jakarta: Gramedia, 2008.

Burhanuddin, Jajat, Ulama Dan Kekuasaan: Pergumulan Elit Muslim Dalam Sejarah Indonesia. Jakarta: Mizan, 2012.

Chaidar, Al. Gerakan Aceh Merdeka: Jihad Rakyat Aceh Mewujudkan Negara Islam. Jakarta: Penerbit Madani Press. 1999. 
Chilcote, Ronald H., Teori Perbandingan Politik; Penulusuran Paradigma, Jakarta: Raja Grafindo Persada 1999.

Dasgupta, Arun K., Acheh in Indonesian Trade and Politics: 1600- 1641. U.S.A: University Microfilms, 1962.

Douglas, George Ritzer, Teori Sosiologi Modern, cet. ke-6 Jakarta: Kencana, 2010.

El-Ibrahimy, M. Nur, Peranan Teungku Muhammad Daud Beureueh dalam Pergolakan di Aceh, Jakarta: Media Dakwah, 2001.

Esposito, Jhon L. (ed)., Ensiklopedi Dunia Islam Modern, Jilid I, Bandung: Penerbit Mizan, 2001.

Gall, Meredith D, Joyce P. Gall \& Walter R. Borg, Educational Research. USA: Pearson Education Inc, 2007.

Garnier, Jules, De Verovering van Kota Blang Temoelit, Samalangan Op 27 Agustus 1877 (Rotterdam: Nijgh \& van Ditmar (Drukker), 1887.

Gayatri, Irine Hiraswari, dan Septi Satriani, (eds.). Dinamika Kelembagaan Desa: Gampong di Era Otonomi Khusus Aceh. Jakarta: LIPI. 2008.

Geertz, Clifford, Kebudayaan dan Agama, Yogyakarta: Kanisius, 2003.

Giddens, Anthony. The Constitution of Society (terjemahan). Malang: Penerbit Pedati. Hurgronje, C. Snouck. 1983. Aceh Di Mata Kolonialis. Jakarta: Yayasan Soko Guru. 2004.

H.J. Banda, Bulan Sabit Dan Matahari Terbit, Islam Indonesia Pada Masa Pendudukan Jepang (Jakarta: Pustaka Jaya,1980.

Hariono, Mempelajari Sejarah secara Efektif, Jakarta: Dunia Pustaka Jaya, 1995.

Hartmann, Michael, The Sociology of Elites, New York: Routledge, 2007.

Harun,Mohd., Memahami Orang Aceh, Bandung: Citapustaka Media Perintis, 2009.

Hasan Saleh, Mengapa Aceh Bergolak, Jakarta: Pustaka Utama Grafiti Press, 1992.

Hasjimi, Ali, 59 Tahun Aceh Merdeka di Bawah Pemerintahan Ratu Jakarta: Bulan Bintang, 1983.

------------, Sejarah Masuk dan Berkembangnya Islam di Indonesia, Bandung: Al-Maarif, 1981.

, Semangat Merdeka 70 Tahun Menempuh Jalan Pergelakan \& Perjuangan (Jakarta: Bulan Bintang, 1985.

Hockett, Homer Carey, Critical Method In Historical Research Writing, New York: Macmilan Company,tt.

Horton, Paul B. dan Chester L. Hunt, Sosiologi (Jilid 2), Jakarta: Erlangga, 2004.

Hosein, Moehammad, Adat Atjeh, Banda Aceh. Banda Aceh: Dinas Pendidikan dan Kebudayaan Propinsi Daerah Istimewa Aceh, 1970.

Hurgronje, Cristian Snouck, De Atjhers, jilid I dan II, Leiden : E.J. Brill, 1893-1894.

Husda, Husaini, "Kiprah Ulama dalam Sejarah Percaturan Politik di Aceh", Jurnal Adabiya,I, 1999.

Husda, Husaini, "Perang Cumbok. Klimak Konflik Ulama dan Uleebalang". Jurnal Adabiya, No.3 Agustus 2000.

Iskandar, Mohammad, dkk, Peranan Elit Agama pada masa revolusi kemerdekaan Indonesia, Jakarta: Proyek Peningkatan Kesadaran Sejarah dan Nilai Trdaisional Depdikbud: 2000.

Ismail, M. Gade, Seuneubok Lada, Uleebalang dan Kumpeni: Perkembangan Sosial Ekonomi di Daerah Batas Aceh Timur 1840-1842, Leiden: Academisch Proefschrift de Rijksuniversiteit tc leiden, 1991.

J. Kreemer, Atjeh II, Leiden : E.J. Briil, 1992.

J. Myron Jacobstein;, Roy M. Mersky, Fundamentals of Legal Research, New York: The Foudation Press, 1973. 
Jakobi, A.K., Aceh Daerah Modal Long March ke Medan Area, (Jakarta: Yayasan Seulawah Malaka Jaya, 1992.

-----------, Aceh Dalam Perang Mempertahankan Proklamasi Kemerdekaan Republik Indonesia 1945-1949 dan Peranan Teuku Hamid Azwar, Jakarta: Gramedia Pustaka Utama, 1998.

Jamil, M. Joenoes Riwayat Barisan "F”" Fujiwaea Kikan di Aceh (Banda Aceh: Pusat Ilmu Sosial, 1975. Ju Lan, Thung, et.al. Klaim, Kontestasi dan Konflik Identitas. Jakarta: Puslit Kemasyarakatan dan Kebudayaan LIPI. 2005.

Kahin, Audrey R., Pergolakan Daerah Pada Awal Kemerdekaan, Jakarta: Grafiti Perss, 1990.

Kartodirdjo, Sartono, Perkembangan Peradaban Priyayi. Yokyakarta: Gadjah Mada University Press, 1993.

-------------, Pemikiran Perkembangan Historiografi di Indonesia Suatu Alternatif, Jakarta: Gramedia, 1982.

Khaldun, Abdurrhman Ibn, Muqaddimah, Beirut : Dar Al-Fikr, t.t.

Kreemer, J., Atjèh Algemeen Samenvattend Overzicht van Land en Volk van Atjèh en Onderhoorigheden,Tweede deel. Leiden: N. V. Boekhandel en drukkerij voorheen e. J. Brill, 1923.

Sejarah Daerah Propinsi Daerah Istimewa Aceh, Departemen Pendidikan dan Kebudayaan, Pusat Penelitian Sejarah dan Budaya, Proyek Penelitian dan Pencatatan Kebudayaan Daerah, 1977/1978.

Shiraisi, Saya S., Young Heroes; The Indonesian family in politics; Studies on Southeast Asia 22 (Published by: Brill https://www.jstor.org/stable/27865375.

Siegel, James T., The Rope of God, Berkeley and Los Angeles: University of California, 1969.

Sitepu, Anthonius, P., Teori-Teori Politik, Yogyakarta: Graha Ilmu, 2012.

Subana M. dkk., Dasar-dasar Penelitian Ilmiah. Bandung : Pustaka Setia. 2005.

Sufi, Rusdi, Gerakan Nasionalisme Di Aceh 1900-1942, Jakarta, Depdiknas, 2000.

Sulaiman, M., Sejarah Aceh: Sebuah Gugatan Terhadap Tradisi, Jakarta: Pustaka Sinar Harapan, 1997.

Suny, Ismail, (eds.). Bunga Rampai Tentang Aceh. Jakarta: Bhratara. 2001.

Suryadinata, Leo.; Evi Arifin.; Aris Ananta. Indonesia's Population Ethnicity and Religion in A Changing Political Landscape. Singapore: ISEAS. 2003.

Suyanta, Sri, Interaksi Ulama dan Umara di Aceh, Jurnal Ar-Raniry, No.80. 2002.

Syamsuddin, Nazaruddin, Revolusi di Serambi Mekkah, Perjuangan Kemerdekaan dan Pertarungan Politik di Aceh 1945-1949, Jakarta: UI-Press, 1999.

Veer, Paul Van T., De Atjeh Orlog, Amsterdam: Uitgeverij De Arbeiderspers, 1969.

Walizer, Michael N. dan Paul L. Wienir, Research Methods and Analysis: Searching for Relationship, terj. Arief Sukadi Sudian, Jakarta: Erlangga, 1991.

Weber, Max, Etika Protestan dan Spirit Kapitalisme, Terj. TW Utomo dan Yusup Priya Sudiarja, Yogyakarta: Pustaka Pelajar, 2006.

Zainuddin, A. Rahman. Kekuasaan Dan Negara: Pemikiran Politik Ibnu Khaldun, Jakarta: Gramedia Pustaka Utama, 1992.

Zamzami, Amran, Jihad Akbar di Medan Area. Jakarta: Bulan Bintang, 1990.

Zuriah, Nurul, Metodologi Penelitian Sosial dan Pendidikan mJakarta : Bumi Aksara, 2005. 